\title{
THE SPECTROPHOTOMETRIC DETERMINATION OF CHROMIUM (VI) USING N, N-DIETHYL-P-PHENYLENEDIAMINE IN SYNTHETICALLY PREPARED WASTEWATER, AND TAP WATER
}

\author{
PARWEen H. SAlEem \\ Dept. of Chemistry, College of Sciences, University of Duhok, Kurdistan Region-Iraq
}

(Received: December 4, 2020; Accepted for Publication: February 7, 2021)

\begin{abstract}
The DPD ( $N$, N-diethyl-p-phenylenediamine) is introduced in the present study as an analytical reagent for the direct, rapid, easy, and sensitive spectrophotometric detection of hexavalent chromium $\mathrm{Cr}$ (VI) species which is health hazard. The oxidization of the colorless DPD (N, N-diethyl-pphenylenediamine) reagent with $\mathrm{Cr}(\mathrm{VI})$ results in a red color DPD radical (DPD ${ }^{\circ+}$ ) at $\mathrm{pH}$ 4.39. The color intensity is directly proportional to the $\mathrm{Cr}$ (VI) concentration. By utilizing a $\mathrm{UV}$-Vis spectrophotometer, the measurement of the produced $\mathrm{DPD}^{\circ+}$ can be identified in term of quantity at $551 \mathrm{~nm}$. The linear calibration graphs for $0.2-2 \mathrm{mg}$. $\mathrm{L}^{-1}$ of $\mathrm{Cr}(\mathrm{VI})$ are obtained with a correlation coefficient value of 0.9997 .

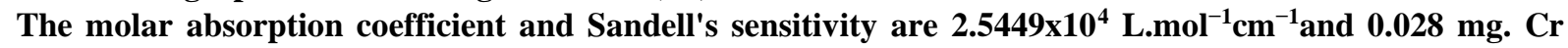
(VI), $\mathbf{c m}^{-2}$, respectively. The present work develops, optimizes, and validates a new spectrophotometric method for determining $\mathrm{Cr}$ (VI) in the samples of the synthetically prepared wastewater and tap water. The method is effectively applied and the findings are statistically evaluated with those of the reference method.
\end{abstract}

KEYWORDS: Chromium, Cr (VI), N, N-diethyl-p-phenylenediamine, Synthetically prepared Wastewater.

\section{INTRODUCTION}

C hromium, as a hazardous organic and inorganic water pollutant, is listed in the U.S. Environmental Protection Agency (EPA) Priority Pollutant List (Jamroz et al., 2019). In human biochemistry, Chromium has a dual paradoxical function. While it forms an essential element in trace amounts, the large quantities of it are both toxic and cancerous (Meneses, Júnior and Costa, 2018), albeit the carcinogenic process mechanism remains unclear (Dima, Sequeiros and Zaritzky, 2015; Vaz et al., 2017).

Permissible $\mathrm{Cr}$ (VI) concentrations as 0.05 mg. $\mathrm{L}^{-1}$ or less have been established and the tracking of their concentration has been made compulsory by both WHO and Japanese environmental guidelines (Yokota et al., 2019). On this basis, $\mathrm{Cr}$ (VI) is regarded as a contaminant in water supplies, at a time when the essentiality and toxicity of chromium are based on its oxidation states. Several oxidation stages, namely 0 to VI, for Chromium are known to exist. Yet, both $\mathrm{Cr}$ (III) and $\mathrm{Cr}$ (VI) are commonly found in their thermodynamically stable forms. Hence, $\mathrm{Cr}$ (VI) is viewed as a contaminant in water supplies (Tóth and Baze 2019).

Accordingly, the development of the analytical procedures to effectively identify chromium is required. Examples of the procedures for determining total chromium and $\mathrm{Cr}(\mathrm{VI})$ in water samples, are FIA with spectrophotometric detection (Meneses, Júnior and Costa, 2018; Zhu et al., 2018; Shekho and Mahmoud 2016) derivative spectrophotometry (Wrobel et al., 1997), ion chromatography coupled with UV-Vis detection (Onchoke, and Salomey, 2016) , spectrophotometric method (Nagaraj et al., 2009: Tayone, 2015: Soomro et al., 2011: Stoyanova, 2005) colorimetric (Parmar, Pillai and Gupta, 2010), and atomic absorption spectrometry (AAS) detection,( Divrikli, Soylak and Elci, 2008; Oreste et al., 2020).

In the expanding analytical areas, viz. environmental, biological, and material monitoring of the trace levels of heavy metal ions, the development of easy and fast analytical techniques, not costly in nature, is heavily demanded. Similiarly the correct detection of $\mathrm{Cr}$ (VI) traces forms a significant task and challenge. 
The spectrophotometric methods, as an analytical method, are quite advantageous in terms of being an easy and low-cost operation (Zou et al., 2019).

The commercial reagent $N, N$-diethyl- $p$ phenylenediamine (DPD) is vastly used as an indicator to determine the various oxidants on treating water (Gokulakrishnan, Mohammed, and Prakash, 2016). By means of just oneelectron transfer, the red DPD can be obtained by the oxidation of the colorless DPD (Liu et al., 2019). In other words, DPD may be oxidized by $\mathrm{Cr}$ (VI) so as to generate $\mathrm{DPD}^{\circ+}$; a process that results in a red color with an intensity that is directly proportional to the concentration of $\mathrm{Cr}$ (VI).

A spectrophotometric method that is based on the reaction between $\mathrm{Cr}$ (VI) and DPD to identify the trace $\mathrm{Cr}$ (VI) concentration in water is not known yet. As such, the current study aims at developing the DPD spectrophotometric method to determine the trace concentration of $\mathrm{Cr}$ (VI) in the synthetically prepared samples of wastewater and tap water.

\section{MATERIALS AND METHODS}

\subsection{Apparatus}

In the current study, an apparatus that consists of a UV-visible spectrophotometer (Jenway, 7315, spectrophotometer) with $1 \mathrm{~cm}$ quartz cell is used to measure the absorbance. Also, a $\mathrm{pH}$ meter for measuring the $\mathrm{pH}$ values (pH-2005, JP Selecta, Spain) is used.

\subsection{Reagents}

For preparing all the solutions, analytical grade reagent chemicals were used. Also, a fresh preparation of buffer solution and double distilled water were used in all the experiments.

Acetate buffer solutions (HAC/AC ${ }^{-}$buffer) $\mathrm{pH}$ 3.6-5.6 were being prepared as the required amounts of equimolar $0.1 \mathrm{M}$ acetic acid and 0.1 $\mathrm{M}$ sodium acetate (trihydrate) were combined.

Phosphate buffer solutions (PBS) $\mathrm{pH}$ 5.8-8.0 were prepared by mixing sufficient amounts of equimolar (1 $\mathrm{M})$ potassium di-hydrogen phosphate and potassium monohydrate phosphate in DDW and the $\mathrm{pH}$ was adjusted by $0.2 \mathrm{M} \mathrm{HCl}$ and $0.2 \mathrm{M} \mathrm{NaOH}$.

A stock standard solution of (1000 mg. $\left.\mathrm{L}^{-1}\right)$ $\mathrm{Cr}$ (VI) was prepared by dissolving $2.8290 \mathrm{~g}$ potassium dichromate $\left(\mathrm{K}_{2} \mathrm{Cr}_{2} \mathrm{O}_{7}\right)$ in double distilled water, then being diluted to a final amount of $1000 \mathrm{ml}$. By the serial dilution, working standard solutions were prepared from an intermediate stock solution $\left(100 \mathrm{mg}\right.$. $\left.\mathrm{L}^{-1}\right)$.

(1000 mg. $\mathrm{L}^{-1}$ ) of N, N-Diethyl-Pphenylenediamine oxalate salt (DPD) was prepared by dissolving $0.1 \mathrm{~g}$ in double distilled water, then being diluted to a final volume of $100 \mathrm{ml}$.

The synthetically prepared Wastewater;

$\mathrm{X}_{1}$ : A solution containing $10 \mathrm{mg}$. $\mathrm{L}^{-1}$ of each ion $\left[\mathrm{Al}^{3+}, \mathrm{Ca}^{2+}, \mathrm{Fe}^{2+}, \mathrm{Pb}^{2+}, \mathrm{Mg}^{2+}\right]$.

$\mathrm{X}_{2}$ : A solution containing $10 \mathrm{mg}$. $\mathrm{L}^{-1}$ of each ion $\left[\mathrm{Cd}^{2+}, \mathrm{Ba}^{2+}, \mathrm{Cr}^{+3}, \mathrm{Na}^{+}, \mathrm{Pb}^{2+}\right]$.

$\mathrm{X}_{3}$ : a mixture of $\left[\mathrm{X}_{1}+\mathrm{X}_{2}\right]$

2.3 The General Procedure

To identify the $\mathrm{Cr}$ (VI) concentration in the proposed DPD method, the following general procedure was carried out: Firstly, $1.4 \mathrm{~mL}$ buffer reagent ( $\mathrm{HAC}^{-} \mathrm{AC}^{-}$buffer, $\mathrm{PH} 4.39$ ), and $1.8 \mathrm{~mL}$ DPD reagent $\left(1000 \mathrm{mg} . \mathrm{L}^{-1}\right)$, were put in $10 \mathrm{~mL}$ calibrated flasks. Secondly, to complete the reaction, the resultant solution was mixed with a $1.0 \mathrm{~mL}$ standard solution containing 2-20 mg. $\mathrm{L}^{-}$ ${ }^{1}$ of $\mathrm{Cr}$ (VI) and held at room temperature for 15 min. The solutions, with distilled water, were then quantitatively diluted to the mark, and the absorbance were evaluated against the blank reagent at $551 \mathrm{~nm}$. The sample was also prepared under similar conditions.

To determine the $\mathrm{Cr}$ (VI) concentration in the synthetically prepared wastewater and tap water, the researchers have adopted general procedures in terms of the proposed DPD method under similar conditions. This method was carried out as follows: Firstly, $1.4 \mathrm{~mL}$ buffer reagent (HAC/AC ${ }^{-}$buffer, $\mathrm{PH} 4.39$ ), and $1.8 \mathrm{~mL}$ DPD reagent $\left(1000 \mathrm{mg}\right.$. $\left.\mathrm{L}^{-1}\right)$, were put in $10 \mathrm{~mL}$ calibrated flasks. Secondly, to complete the reaction, the resultant solution was mixed with a $5.0 \mathrm{~mL}$ standard solution containing $2-20 \mathrm{mg}$. L${ }^{1}$ of $\mathrm{Cr}$ (VI) and held at room temperature for 15 min. The solutions, with distilled water, were then quantitatively diluted to the mark, and the absorbances were evaluated against the blank reagent at $551 \mathrm{~nm}$.

The $\mathrm{Cr}$ (VI) concentration in water samples was calculated from the measured absorbance at $551 \mathrm{~nm}$ by the Eq.:

$[\mathrm{Cr}(\mathrm{VI})]_{\text {sample }}=\Delta \mathrm{A} \mathrm{V}_{\text {final }} / \gamma \varepsilon 1 \mathrm{~V}_{\text {sample }}$

where $\Delta \mathrm{A}$ is the absorbance at $551 \mathrm{~nm}$ after subtracting the blank absorbance; $\gamma$ represents the stoichiometric factor of $\mathrm{DPD}^{\circ+}$ generation identified in $\gamma=k_{\mathrm{s}} / \varepsilon$ equation; $k_{s}$ is the calibration curve slope of pure water gained at 
$551 \mathrm{~nm}$; and $\varepsilon$ stands for the coefficient of the molar absorption of $\mathrm{DPD}^{-+}$at $551 \mathrm{~nm}$ which was measured at $\mathrm{pH} 4.39$ based on the reaction between chlorine and DPD in order to produce $\mathrm{DPD}^{++}$(Palin, 1957). The value of $\varepsilon$ was found out to be $\varepsilon=2.13 \times 10^{4} \mathrm{~L} \cdot \mathrm{mol}^{-1} \mathrm{~cm}^{-1}$. Such a value corresponded to the value $2.10 \times 10^{4}$ L. $\mathrm{mol}^{-1} \mathrm{~cm}^{-1}$ reported by Bader, Sturzenegger, and Hoigné, (1988), and the value $2.17 \times 10^{4}$ L. $\mathrm{mol}^{-1} \mathrm{~cm}^{-1}$ reported by Zou et al. (2019); 1 represents the path length of the cuvette; $\mathrm{V}_{\text {sample }}$ refers to the volume of the tested $\mathrm{Cr}$ (VI) samples; and $\mathrm{V}_{\text {final }}$ is the final volume after adding all solutions.

\section{RESULTS AND DISCUSSION}

\subsection{Absorption Spectra}

Fig. 1 shows the absorption spectrum (400$600 \mathrm{~nm}$ ) of the DPD solution after reacting with $\mathrm{Cr}$ (VI) under the optimal conditions. It demonstrates that the produced $\mathrm{DPD}^{*}$ has a broad and intense absorption spectrum in the visible region with two peaks of absorption at $510 \mathrm{~nm}$ and $551 \mathrm{~nm}$. This is in agreement with the absorption spectral features listed by other researchers in this field, namely Liu et al., 2018 and Zou et al., 2019.

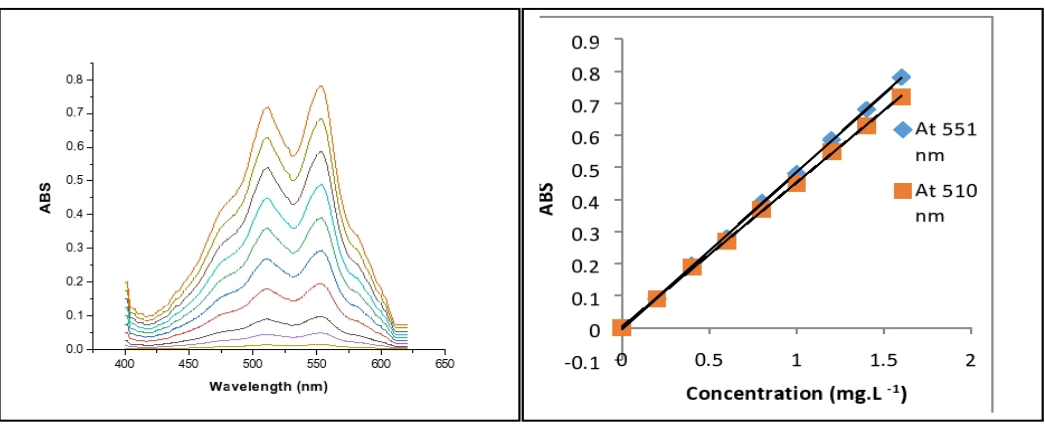

Fig. 1 The absorption spectrum of reaction product of different $\mathrm{Cr}$ (VI)

concentrations and DPD

It is worthy to outline that no change in the absorption curves and peaks with the $\mathrm{Cr}$ (VI) dose was reported. Additionally, there was an increase in the values of absorbance of the produced $\mathrm{DPD}^{++}$at 510 and $551 \mathrm{~nm}$ which was concomitant with the increasing concentration of $\mathrm{Cr}$ (VI). The standard curves got a remarkable linear relationship for $\mathrm{Cr}(\mathrm{VI})$ concentration in the range of $0.2-2 \mathrm{mg}$. $\mathrm{L}^{1}$ and $\mathrm{R}^{2}$ values were up to 0.9997 , and the sensitivities were computed as $2.33 \times 10^{4} \quad$ L. $\mathrm{mol}^{-1} \mathrm{~cm}^{-1}$ and $2.54 \quad \times 10^{4}$ L. $\mathrm{mol}^{-1} \mathrm{~cm}^{-1}$ corresponding to $510 \mathrm{~nm}$ and 551 $\mathrm{nm}$. Accordingly, a spectrophotometric method based on DPD as a reagent for measuring traces of $\mathrm{Cr}(\mathrm{VI})$ concentration at $551 \mathrm{~nm}$ and relying on the reaction of oxidation between DPD and $\mathrm{Cr}$ (VI) has been suggested in this paper. Since the value of absorbance at $551 \mathrm{~nm}$ was higher than the absorbance value at $510 \mathrm{~nm}, 551 \mathrm{~nm}$ was chosen as the wavelength of detection in this study.

3.2 The Effect of $\mathrm{pH}$ and buffer Volume

To determine $\mathrm{Cr}$ (VI) in the $\mathrm{pH}$ range of 3.9 8.8, there had been an intensive investigation of the effects of different buffer solutions. Fig. 2 indicates that the highest analytical signal of the buffer system was recorded at $\mathrm{pH}$ 4.39. As such, it was accounted for as the optimum $\mathrm{pH}$ value for forthcoming investigations or studies.

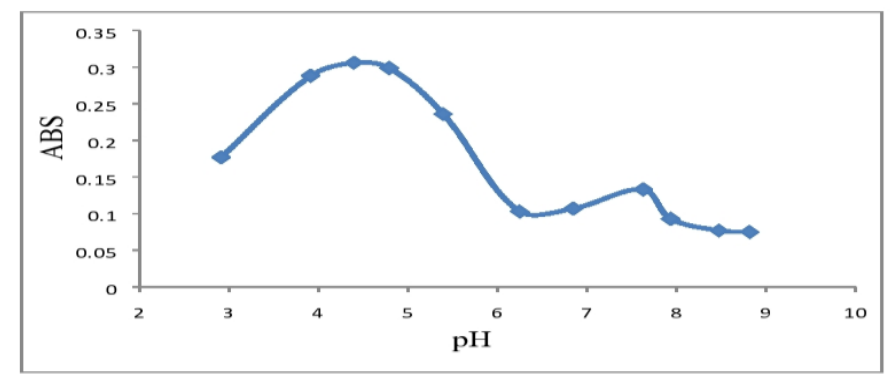

Fig. 2 Effect of $\mathrm{pH}$ on the absorbance of the reaction product of $\mathrm{Cr}(\mathrm{VI})$ and DPD 
Additionally, the volume of the buffer solution that gave the highest analytical signal was also investigated within the range of 0.2-2.0 $\mathrm{mL}$ (Fig. 3). On the basis of the arrived at results,
$1.4 \mathrm{~mL}$ of buffer solution at $\mathrm{pH} 4.39$ was applied to the aqueous solutions to maintain the $\mathrm{pH}$ already referred to in further studies.

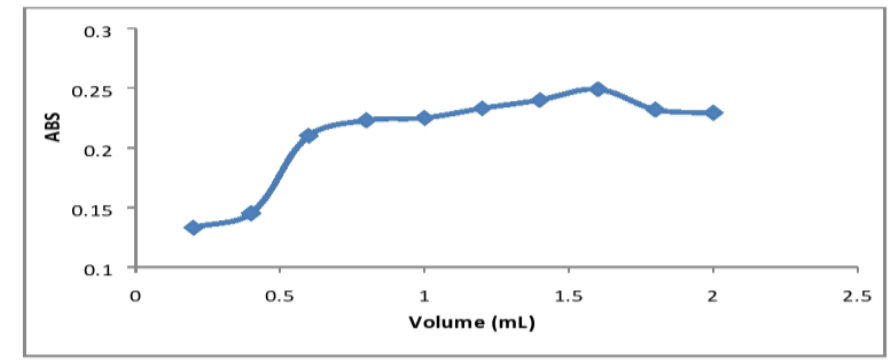

Fig. 3 Effect of buffer volume on the absorbance of the reaction product of $\mathrm{Cr}$ (VI)

and DPD

3.3 The effect of reagent concentrations.

A different excess of the DPD reagent was added to the concentration range $\mathrm{Cr}(\mathrm{VI})$, followed by measuring the absorbance. Fig. 4 shows that the addition of $1.8 \mathrm{ml}\left(1000 \mathrm{mg} . \mathrm{L}^{-1}\right)$ of DPD resulted in the achievement of maximum absorbance.

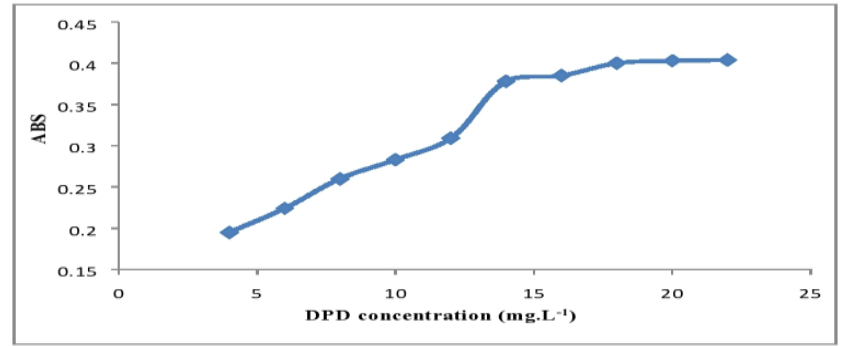

Fig. 4 Effect of DPD concentration on the absorbance of the reaction product of $\mathrm{Cr}$

(VI) and DPD

\subsection{The Effect of surfactant.}

Various surfactants, namely [nonionic polyoxyethylene sorbitan mono-palmitate (Tween40),TritonX100]; cationic,cetyltrimethylammonium bromide (CTAB); and anionic, sodium dodecyl sulfate (SDS) had been tested.
Table 1 shows that maximum absorbance was observed in the $10 \%$ cetyltrimethylammonium bromide $(\mathrm{CTAB})$ medium and aqueous solution without surfactants. Hence, the aqueous solution was used in the determination process.

Table (1): Effect of surfactants on the absorbance of the reaction product of $\mathrm{Cr}$ (VI) and DPD

\begin{tabular}{ll}
\hline Surfactant & ABS \\
\hline Tween-40 & 0.370 \\
\hline Triton X-100 & 0.368 \\
\hline CTAB & 0.479 \\
\hline SDS & 0.336 \\
\hline Without Surfactant & 0.438 \\
\hline
\end{tabular}

\subsection{The effect of time and temperature}

The generated $\mathrm{DPD}^{+}$stability in the suggested DPD method was evaluated by investigating, at various temperatures $\left(25-45^{\circ} \mathrm{C}\right)$ and at different times, the changes in $\mathrm{DPD}^{*+}$ absorbance at $551 \mathrm{~nm}$, following the reaction between DPD and Cr (VI) pure water. Fig. 5 shows that the reaction speed increases with the increase in temperature; and that a maximum, yet unstable, absorption occurs at a temperature of $45^{\circ} \mathrm{C}$ after 5 minutes. At room temperature, and after the elapse of 15 minutes, the maximum absorption remained constant for more than two hours. This absorption stability shared consistency with the stability revealed by Bader et al. (1988), where $\mathrm{DPD}^{-+}$was produced by the oxidation of DPD with $\mathrm{H}_{2} \mathrm{O}_{2}$ in the existence of 
peroxidase at $\mathrm{pH}$ 6.0. Accordingly, room of the remaining experiments. temperature could be selected for the completion

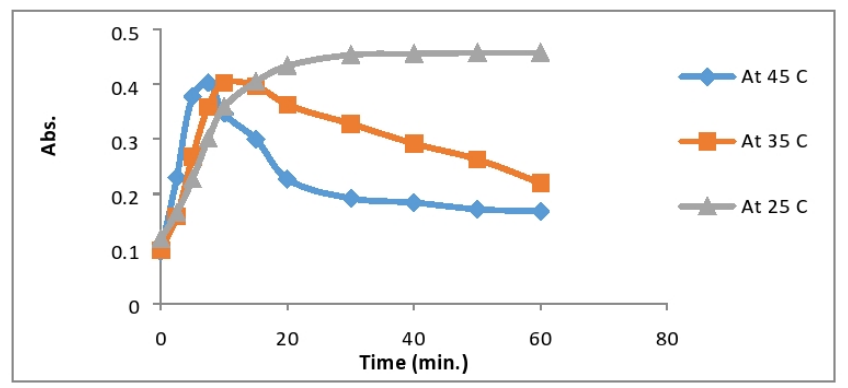

Fig. 5 Effect of time and temperature on the absorbance of the reaction product of

$\mathrm{Cr}$ (VI) and DPD

Table (2) demonstrates the statistical treatments, viz. linear ranges, limits of detection, limits of quantification, calibration equation, and correlation coefficient for $\mathrm{Cr}$ (VI), of the calibration results.

The calculated stoichiometric coefficient $(\gamma)$ of DPD + produced in the suggested DPD method was 1.192 .

In an attempt to determine the precision and accuracy of the proposed method, the researchers have duplicated four test trials to get calculations on the three different concentrations of the standard $\mathrm{Cr}$ (VI) solutions. The accuracy level of the method was tested with a relative error of (E \%), whereas precision was checked with a relative standard deviation (RSD) of the same solutions. The results illustrated in Table 3 indicate that the method has exhibited good accuracy and precision.

Table (2) :Analytical data for the determination of $\mathrm{Cr}(\mathrm{VI})$

\begin{tabular}{ll}
\hline Parameters & \\
\hline$\lambda_{\max }$ & $550 \mathrm{~nm}$ \\
\hline Stability & $1 \mathrm{~h}$ \\
\hline Linear regression equation & $\mathrm{y}=0.4895 \mathrm{x}-0.0047$ \\
\hline Correlation coefficient $\left(\mathrm{R}^{2}\right)$ & 0.9997 \\
\hline Linear range $\left(\mathrm{mg} . \mathrm{L}^{-1}\right)$ & $0.2-2$ \\
\hline Limit of detection $\left(\mathrm{mg} . \mathrm{L}^{-1}\right)$ & 0.0421 \\
\hline Limit of Quantification $\left(\mathrm{mg} . ~^{-1}\right)$ & 0.127 \\
\hline Molar absorptivity $\left(\mathrm{L} \cdot \mathrm{mol}^{-1} \mathrm{~cm}^{-1}\right)$ & $2.5449 \times 10^{4}$ \\
\hline Sandell's sensitivity $\left(\mathrm{mg}_{\mathrm{cm}} \mathrm{cm}^{-2}\right)$ & 0.028 \\
\hline stoichiometric factor $\mathrm{\gamma}$ & 1.192 \\
\hline
\end{tabular}

Table (3): Accuracy and precision of the present method

\begin{tabular}{cccccc}
\hline Compound & $\begin{array}{c}\text { Conc. of } \mathrm{Cr}(\mathrm{VI}) \\
\left(\mathrm{mg} . \mathrm{L}^{-1}\right)\end{array}$ & $\begin{array}{c}\text { Mean } \\
(\mathrm{abs})\end{array}$ & $\mathrm{E}(\%)$ & $\mathrm{SD}$ & $\mathrm{RSD} \%$ \\
\hline chromium(VI) & 0.4 & 0.221 & $+3.70 \%$ & 0.015 & 0.068 \\
\cline { 2 - 6 } & 1.0 & 0.362 & +1.69 & 0.002 & 0.007 \\
\cline { 2 - 6 } & 1.6 & 0.542 & $-1.45 \%$ & 0.003 & 0.006 \\
\hline
\end{tabular}

\section{INTERFERENCES}

To assess the analytical applicability of the method used for determining $\mathrm{Cr}(\mathrm{VI})$, the effect of some interfering substances, that could be 
found in the water, was tested by analyzing a standard solution of $\mathrm{Cr}(\mathrm{VI})\left(0.8 \mathrm{mg}\right.$. $\left.\mathrm{L}^{-1}\right)$ with the addition of increasing amounts of interfering

Table (4) : Tolerance of non-target ions. The tolerable concentration ratios pertinent to $\left(0.8 \mathrm{mg} . \mathrm{L}^{-1}\right)$ of $\mathrm{Cr}(\mathrm{VI})$ for interference at $( \pm$ 5) $\%$ level are listed in Table (4).

\begin{tabular}{|c|c|c|c|c|c|}
\hline Ion & $\begin{array}{c}\text { Tolerance level } \\
\left(\mathrm{mg} . \mathrm{L}^{-1}\right)\end{array}$ & Ion & $\begin{array}{c}\text { Tolerance level } \\
\left(\mathrm{mg} . \mathrm{L}^{-1}\right)\end{array}$ & Ion & $\begin{array}{c}\text { Tolerance level } \\
\left(\mathrm{mg} . \mathrm{L}^{-1}\right)\end{array}$ \\
\hline $\mathrm{A} 1^{3+}$ & 100 & $\mathrm{Cd}^{2+}$ & 100 & Oxalate & 100 \\
\hline $\mathrm{Ca}^{2+}$ & 80 & $\mathrm{Ba}^{2+}$ & 100 & Sulfate & 100 \\
\hline $\mathrm{Cr}(\mathrm{III})$ & 100 & $\mathrm{Mn}^{+2}$ & 100 & Chloride & 40 \\
\hline $\mathrm{Fe}^{2+}$ & 80 & $1 \mathrm{O}_{3}{ }^{-}$ & 100 & Nitrate & 100 \\
\hline $\mathrm{Na}^{+}$ & 100 & $\mathrm{HCO}_{3}{ }^{-}$ & 100 & $\mathrm{PO}_{4}^{3-}$ & 100 \\
\hline $\mathrm{Pb}^{2+}$ & 100 & $\mathrm{~F}-$ & 100 & Acetate & 100 \\
\hline $\mathrm{Ni}^{2+}$ & 60 & $\mathrm{CO}_{3}{ }^{2-}$ & 100 & EDTA & 100 \\
\hline $\mathrm{Cu}^{2+}$ & 20 & Tartarate & 100 & & \\
\hline $\mathrm{Mg}^{2+}$ & 100 & Sulphite & 100 & & \\
\hline
\end{tabular}

\section{APPLICATION}

The accuracy of the proposed method was evaluated on the basis of the analysis of the water samples. The procedure was successfully applied to determine $\mathrm{Cr}(\mathrm{VI})$ in both Synthetically prepared Wastewater, and tap water samples by means of the standard method as $\left(2,4,6,8\right.$, and $12 \mathrm{mg} . \mathrm{L}^{-1}$ of $\mathrm{Cr}(\mathrm{VI})$ were added to water samples (Fig. 6). Table 5 shows that the slope of the aqueous standard and the standard addition graphs is identical. This means that there was no interference by the water sample matrix.

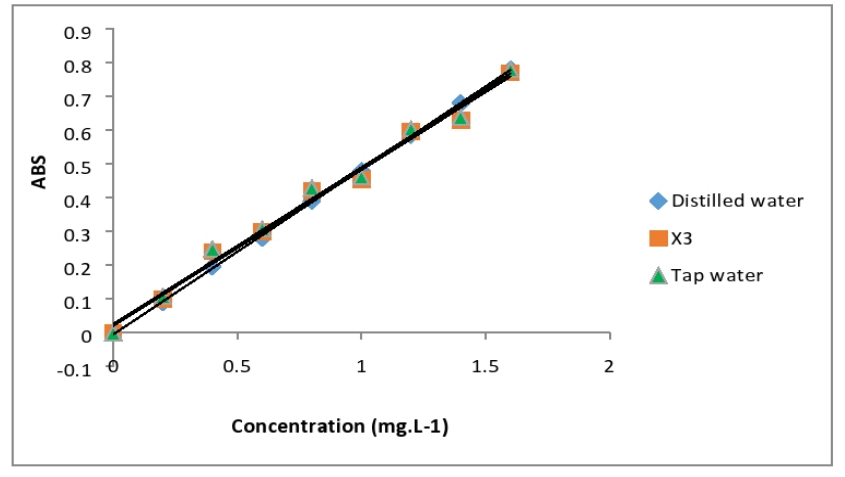

Fig. 6 Standard addition calibration graph

Table (5) : Analytical data of the standard addition calibration graph.

\begin{tabular}{llll}
\hline Sample & Linear regression equation & $\begin{array}{l}\text { Correlation } \\
\text { coefficient }\end{array}$ & $\begin{array}{l}\text { Molar absorptivity } \\
\text { liter. } \mathrm{mol}^{-1} \mathrm{~cm}^{-1}\end{array}$ \\
\hline Standard $\mathrm{Cr}(\mathrm{VI})$ solution+ distilled water & $\mathrm{Y}=0.4895 \mathrm{X}-0.0047$ & 0.9997 & $2.5449 \times 10^{4}$ \\
\hline $\begin{array}{l}\text { Standard } \mathrm{Cr}(\mathrm{VI}) \text { solution+ distilled water }+ \\
\mathrm{X}_{3}\end{array}$ & $\mathrm{Y}=0.4615 \mathrm{X}-0.0208$ & 0.9893 & $2.3991 \times 10^{4}$ \\
\hline Standard $\mathrm{Cr}(\mathrm{VI})$ solution + tap water & $\mathrm{Y}=0.4641 \mathrm{X}-0.0258$ & 0.9888 & $2.4129 \times 10^{4}$ \\
\hline
\end{tabular}

Table (6): Analytical results of $\mathrm{Cr}(\mathrm{VI})$ determination in synthetic and tap water samples.

\begin{tabular}{lllllllll}
\hline Sample & \multicolumn{7}{l}{ Proposed method } & \multicolumn{7}{c}{ Reference method } \\
\cline { 2 - 9 } & $\begin{array}{l}\text { Added } \\
\left(\mathrm{mg.} \mathrm{L}^{-1}\right)\end{array}$ & $\begin{array}{l}\text { Found } \\
\left(\mathrm{mg} . \mathrm{L}^{-1}\right)\end{array}$ & $\begin{array}{l}\text { Recovery } \\
(\%)\end{array}$ & $\begin{array}{l}\text { S.D. } \\
(\%) \\
\mathrm{n}=4\end{array}$ & $\begin{array}{l}\text { Added } \\
\left(\mathrm{mg} . \mathrm{L}^{-1}\right)\end{array}$ & $\begin{array}{l}\text { Found } \\
\left(\mathrm{mg} . \mathrm{L}^{-1}\right)\end{array}$ & $\begin{array}{l}\text { Recovery } \\
(\%)\end{array}$ & $\begin{array}{l}\text { S.D. } \\
(\%)\end{array}$ \\
\hline Synthetic sample $\mathrm{X}_{1}$ & 8 & 8.13 & $101.6 \pm 0.21$ & 0.10 & 8 & 7.86 & $\begin{array}{l}98.25 \pm 0.4 \\
7\end{array}$ & 0.22 \\
\hline
\end{tabular}




\begin{tabular}{|c|c|c|c|c|c|c|c|c|}
\hline Synthetic sample $X_{2}$ & 8 & 8.99 & $99.9 \pm 0.55$ & 0.26 & 8 & 8.87 & $\begin{array}{l}99.18 \pm 0.3 \\
4\end{array}$ & 0.16 \\
\hline \multirow[t]{2}{*}{ Tap water sample } & 8 & 8.50 & $99.5 \pm 0.21$ & 0.1 & 8 & 8.31 & $98.2 \pm 0.21$ & 0.1 \\
\hline & ----- & 0.44 & ----- & & ----- & 0.45 & & \\
\hline
\end{tabular}

For the purpose of comparison, the reference method was used for analyzing the samples (Suvardhan, et al, 2005) and came out with the results presented in Table (6). The results demonstrate a strong agreement between the results arrived at by the proposed method and those of the reference method.

The results of the suggested method and the reference method have been put into comparison by means of the F-test and t-test. The comparison outlines no significant dissimilarities between the two methods in terms of accuracy and precision $(\mathrm{t}$-calculated $=0.72<\mathrm{t}$-table $=2.31$ and F-test calculated $=3.52<$ F-table $=5.05$ with a limit of confidence of $95 \%$ ).

\section{CONCLUSION}

The proposed method is based on an oxidation-reduction coloring reaction where $\mathrm{Cr}$ (VI) can oxidize the DPD reagent to form a redcolored water-soluble product $(\mathrm{DPD} \bullet+)$ at $\mathrm{pH}$ 4.39. The product can remain stable for more than two hours and have the maximum absorption at $551 \mathrm{~nm}$. The DPD method adopted to determine the trace $\mathrm{Cr}$ (VI) concentration in the water samples has proved to be beneficial as $\mathrm{Cr}$ (VI) reacts very rapidly with DPD. The suggested process is also very easy for measuring the concentration of $\mathrm{Cr}$ (VI) in water and requires a cheap UV spectrometer and lowcost reagents. It is further quite economical for measuring Cr (VI). Also, the DPD method is highly sensitive $\left(2.5449 \times 10^{4} \mathrm{~L} \cdot \mathrm{mol}^{-1} \mathrm{~cm}^{-1}\right)$ and more suitable for low $\mathrm{Cr}$ (VI) concentrations in water $\left(0.2-2 \mathrm{mg} \cdot \mathrm{L}^{-1}\right)$. Finally, the DPD method is accurate and suitable for measuring the $\mathrm{Cr}$ (VI) concentrations in the synthetic and natural water samples that contain a number of colored substances.

\section{REFERENCES}

Bader, H., Sturzenegger, V., Hoigné, J., 1988. Photometric method for the determination of low concentrations of hydrogen peroxide by the peroxidase catalyzed oxidation of $\mathrm{N}, \mathrm{N}$ diethyl-p-phenylenediamine (DPD). Water Res. 22, 1109-1115.
Dima J. B., Sequeiros C., and Zaritzky, N. E. (2015), Hexavalent chromium removal in contaminated water using reticulated chitosan micro/nanoparticles from seafood processing wastes, Chemosphere 141, 100-111. http://dx.doi.org/10.1016/j.chemosphere.2015. $\underline{06.030}$

Divrikli, U., Soylak, M., and Elci, L. (2008), Determination of total chromium by flame atomic absorption spectrometry after coprecipitation by cerium (IV) hydroxide, Environ Monit Assess, 138, 167-172. https://doi.org/10.1007/s10661-007-9754-7

Gokulakrishnan, S. , Mohammed, A., and Prakash, H., (2016), Determination of persulphates using $\mathrm{N}, \mathrm{N}$-diethyl-p-phenylenediamine as colorimetric reagent: Oxidative coloration and degradation of the reagent without bactericidal effect in water, Chemical Engineering Journal, 286, 223-231.

Jamroz, E., Kocot, K., Zawisza, B., Talik, E., Gagor, A., and Sitko R. (2019), A green analytical method for ultratrace determination of hexavalent chromium ions based on microsolid phase extraction using amino-silanized cellulose membranes, Microchemical Journal, 149.

https://doi.org/10.1016/j.microc.2019.104060.

Liu, X., Cai, H., Zou, J., Pang, Z., Yuan, B., Zhou, Z., Cheng, Q., (2018), Spectrophotometric determination of trace permanganate in water with N,N-diethyl-p-phenylenediamine (DPD), Chemosphere, 8,1-30.

doi: 10.1016/j.chemosphere.2018.08.087.

Meneses, D., Júnior J-G. F., and Costa de Oliveira P. C. (2018), FIA-coupled spectrophotometric method for determination of $\mathrm{Cr}$ (VI) traces in natural waters: application of in-line dissolution of 1,5-diphenylcarbazide after heat treatment and activated alumina as adsorbent for preconcentration, Environ Monit Assess 190:617.

https://doi.org/10.1007/s10661-018-6984-9

Nagaraj, P., Aradhana, N., Shivakumar, A., Shrestha, A. K., and Gowda, A. k. (2009), Spectrophotometric method for the determination of chromium (VI) in water samples, Environ Monit Assess 157,575-582. doi 10.1007/s10661-008-0557-2

Onchoke K. K., and Salomey A. S. (2016), Determination of Hexavalent Chromium (Cr(VI)) Concentrations via Ion 
Chromatography and UV-Vis Spectrophotometry in Samples Collected from Nacogdoches Wastewater Treatment Plant, East Texas (USA), Advances in Environmental Chemistry,2016. http://dx.doi.org/10.1155/2016/3468635

Oreste, E. Q., De Souza, A. O., Pereira, C. C., Bonemann, D. H.,Vieira, M. A., and Ribeiro, A. S. (2020), Evaluation of sample preparation methods for the determination of $\mathrm{Cd}, \mathrm{Cr}$ and $\mathrm{Pb}$ in ceramic tableware by graphite furnace atomic absorption spectrometry, Analytical Letters, 53, 3. https://doi.org/10.1080/00032719.2019.16557 $\underline{59}$.

Parmar, P., Pillai, A. K., and Gupta,V. K. (2010),An Improved Colorimetric Determination of Micro Amounts of Chromium(VI) and Chromium(III) Using p_Aminoacetophenone and Phloroglucinol in Different Samples, Journal of Analytical Chemistry,65,6,582-587. doi:10.1134/S1061934810060067.

Palin, A.T., (1957), The determination of free and combined chlorine in water by the use of diethyl-p-phenylenediamine, J. Am. Water Works Ass. 49, 873-880.

Shekho, N. H., and Mahmoud H. A. (2016), Spectrophotometric Determination of Chromium Using Promethazine Hydrochloride - Application in Various Samples, Ibn AlHaitham Journal for Pure \& Appl. Sci. , 29, 2.

Soomro, R., Ahmed, M. J.,*and Memon N. (2011), Simple and rapid spectrophotometric determination of trace level chromium using bis (salicylaldehyde) orthophenylenediamine in nonionic micellar media, Turkish Journal of Chemistry , 35, 155 - 170. doi:10.3906/kim0911-33.

Stoyanova , A. M. (2005), Catalytic Spectrophotometric Determination of Chromium, Turkish Journal of Chemistry , 29, 367-375.

Suvardhan, K., Ramanaiah, S., Kumar, K. S., Rekha, D., Bhagan, U., Knaidu, G. R., Naidu, G. K., Sastry, B.S., and Chiranjeevi, P. (2005), Spectrophotometric Determination of Chromium in Water, and Pharmaceutical Samples Using 1-Naphthol, E-Journal of Chemistry, 2, 1, 6-14.
Tayone, J.C. (2015), Spectrophotometric Determination of Chromium (VI) in Canned Fruit Juices, International Journal of Sciences: Basic and Applied Research (IJSBAR), 19, 1, 426-432.

http://gssrr.org/index.php?journal=JournalOfB asicAndApplied

Tóth, J., and Baze Y. (2019), Development of a New Kinetic Spectrophotometric Method for the Determination of Chromium with an Optical Probe, Applied Spectroscopy, 73, 5. https://doi.org/10.1177\%2F000370281881240 $\underline{1}$

Vaz, R., Bettini, J., Júnior, Jos`e G. F., Lima E-D. S., Wander G. B., Santos J.C., and, Schiavon, M. A. (2017) High luminescent carbon dots as an eco-friendly fluorescence sensor for $\mathrm{Cr}(\mathrm{VI})$ determination in water and soil samples, Journal of Photochemistry and PhotobiologyA:Chemistry,September,346:502 .http://dx.doi.org/doi:10.1016/j.jphotochem.20 17.06.047.

Wrobel, K., Kazimierz W., Lopez-de-Alba, P. L., and Lopez-Martinez L. (1997), Enhanced spectrophotometric determination of chromium (VI) with diphenylcarbazide using internal standard and derivative spectrophotometry, Talanta, 44, 2129-2136. https://doi.org/10.1016/S0039-9140(97)000921

Yokota, Y., Manaka, A., Tafu, M., Kato, Tomita, T., and Akazawa,T. (2019), Simple colorimetric analysis for determining hexavalent chromium with high sensitivity via homogeneous liquidliquid extraction, Bulletin of the Chemical Society of Japan (BCSJ), 24, doi:10.1246/bcsj.20180351

Zhu, X., Deng, Y., Li, P., Yuan, D., and Ma, J. (2019), Automated syringe-pump-based flow-batch analysis for spectrophotometric determination of trace hexavalent chromium in water samples, Microchemical Journal, 145, March, 1135-1142.

https://doi.org/10.1016/j.microc.2018.12.040.

Zou, J., Cai, H., Wang, D., Xiao, J., Zhou, Z., and Yuan, B., (2019) ,Spectrophotometric determination of trace hydrogen peroxide via the oxidative coloration of DPD using a Fenton system, Chemosphere, 224, 646652.https://doi.org/10.1016/j.chemosphere.201 9.03.005 